\title{
(息)
}

Citation:

Abram, SA (2016) Jokkmokk: Rapacity and Resistance in Sápmi. In: Postcolonial Perspectives on the European High North: Unscrambling the Arctic. Palgrave. ISBN 978-1-137-58817-3 DOI: https://doi.org/10.1057/978-1-137-58817-3_3

Link to Leeds Beckett Repository record:

https://eprints.leedsbeckett.ac.uk/id/eprint/3271/

Document Version:

Book Section (Accepted Version)

The aim of the Leeds Beckett Repository is to provide open access to our research, as required by funder policies and permitted by publishers and copyright law.

The Leeds Beckett repository holds a wide range of publications, each of which has been checked for copyright and the relevant embargo period has been applied by the Research Services team.

We operate on a standard take-down policy. If you are the author or publisher of an output and you would like it removed from the repository, please contact us and we will investigate on a case-by-case basis.

Each thesis in the repository has been cleared where necessary by the author for third party copyright. If you would like a thesis to be removed from the repository or believe there is an issue with copyright, please contact us on openaccess@leedsbeckett.ac.uk and we will investigate on a case-by-case basis. 


\section{Jokkmokk: Rapacity and Resistance in Sápmi}

Simone Abram

\section{Introduction: Reindeer, mines, and tourists}

Stories about "scrambles," from Africa to the Arctic, tend to hinge on a vision of companies and nations racing to gain ownership of resources in other parts of the world, usually areas with rich resources, poor or sparse populations, and weak governments. While the image of greedy states and corporations falling over each other to ransack pristine ecological areas and their peoples is emotionally charged, it is a narrative that merges and dominates what are in fact distinct, complex, and often multi-directional processes with both locally specific and historically peculiar effects. Resistance to new mining concessions in northern Fennoscandia, for example, does not arise from a pristine natural environment, but on the back of historical large-scale mining and industrial exploitation. Sámi activists protesting against colonial exploitation are not a "helpless" indigenous people, but Nordic citizens bounded in familial and social histories of forced relocation and disenfranchisement. Nor has Sámi resistance appeared recently in the history of Nordic colonisation; rather, the crushing of uprisings in the nineteenth century provides the general backdrop for current political activism and the ambivalent unification of different Sámi groups.

In their popular book of the same name, Sale and Potapov's story of the "Scramble for the Arctic" (2010) builds on histories of "first contact" by property-owning European colonisers staking claims to land that was inhabited by others, and views claims and counter-claims for Arctic resources as compromising the many indigenous peoples of the Arctic regions. The story tells of ecological ransack as Arctic mammals were hunted to, or near to, extinction one after another to feed first a fur trade then a whaling bonanza, with indigenous people both complicit and exploited; it then traces the gradual emergence of international treaties and laws as repeated attempts to curtail the decimation of species and ecologies in the High North. Even as these conflicts would eventually lead to the establishment of rights for peoples of the North, Sale and Potapov show international investors and industrialists continuing to treat the Arctic as a pot of gold, rich for the picking; as a treasure trove for whoever dares to delve in, and extract what they can (see Huggan in this volume). As Craciun observes, although the scale of the current global scramble for Arctic resources may be new, the scramble itself is "a centuries-long mad pursuit that has not diminished in interest for the colonial and commercial powers involved."1

At the end of the book, Sale and Potapov note the increase in Arctic cruise tourism, a rise which has been similarly rapid and unregulated, but they make little of the links between these trajectories apart from acknowledging the increasing access for tourist ships enabled by changing ice conditions and shipping practices. However, a slight shift in focus is enough to reveal persistent links and conflicts between expedition-exploration, tourism, resource extraction and indigenous resistance throughout the colonial history of the European High North. As I have argued elsewhere (see Abram and Lund 2016), tourism has followed expeditionary journeys from the European continent, building on the romantic visions of terra

\footnotetext{
${ }^{1}$ Adriana Craciun, “The Scramble for the Arctic," Interventions, 11 no. 1 (2009), 109.
} 
incognita, the mysteries of the imagined North, and the sublime experiences it offers. From the mid nineteenth century onwards, cruise tourism to the European Arctic regions was rapidly established, undoubtedly benefiting from the marketing effects of the exhibition of Sámi herding families at European expositions, which added considerably to the exoticism of the destination.

Cathrine Baglo's account of exhibited Sámi herders is important in this context, since she argues that Sámi families exhibited in Europe, such as at the Natural Science Museum of London, need not necessarily be seen as unwitting victims of European race-exoticism (2011). On the contrary, it seems quite feasible that the herders Jens and Karen Thomasen took up the invitation from William Bullock to bring reindeer to Scotland, and then to perform on the London stage in 1822-3, surely an exciting prospect for any well-travelled family. Later exhibitions elsewhere in Europe and the USA were more firmly situated in neo-Darwinist discourses of racial stereotyping, as parodied by Gomez-Peña (1996; see also Fusco and Gomez-Peña 1992), but Baglo's telling of the story of exhibited humans reminds us that the people on display were not always "exploited slaves," but may have been looking to take the opportunity to educate European audiences on their own lives and experiences in a manner that could be styled "resistance." More broadly, it confirms that tourism and resistance have long accompanied the gathering of Arctic resources and the promulgation of narratives about the High North in European and American contexts, links that continue today through the various forms of performance bound up in the postcolonial context (see Picard 2011).

Indeed, colonial themes and trappings in tourism have been the subject of critique for as long as social scientists have studied tourism (Nash 1989). It has been a good while since Ed Bruner and Barbara Kirshenblatt-Gimblett encapsulated their critique of the performance of colonialism for tourists in a depiction of the serving of tea and scones with accompanying Maasai dancing on a white ranch in Kenya (Bruner and Kirshenblatt-Gimblett 1994). As Bruner and Kirschenblatt-Gimblett would remark at the time, "tourism gives tribalism and colonialism a second life by bringing them back as representations of themselves and circulating them within an economy of performance." ${ }^{2}$ Kenya is a long way from the Arctic, to be sure, but tourism tropes and trappings travel, and there is no reason to suspect that tourists who travel to Kenya do not also set their sights on the North, pursuing experiences of the exotic across the globe.

Critiques of tourism as representations of "culture," and the exploitation of "native" arts and knowledge for tourism development, have been central concerns in social science studies of tourism, with the question of colonialism a recurrent worry (Palmer 1994). Indeed, it is now almost impossible to think about tourism without the question of colonialism hoving into view: for, as Anne-Marie d'Hauteserre puts it, "postcolonialism and tourism both perpetuate myths of the colonial exotic." 3 Amid the so-called scramble for resources in northern Sweden, local resistance to industrial developments are being played out, at least in part, through the tourism performances that are the focus of this chapter, with government mining concessions, foreign mining companies, reindeer herders and environmental activists all performing set-piece roles in a deadly serious confrontation over Arctic futures.

\footnotetext{
${ }^{2}$ Edward Bruner and Barbara Kirshenblatt-Gimblett, "Maasai on the Lawn: Tourist Realism in East Africa," Cultural Anthropology 9, no. 2 (1994): 435.

3 Anne-Marie D'Hauteserre, "Postcolonialism, Colonialism and Tourism," in A Companion to Tourism, ed. by Alan Lew, C. Michael Hall and Allan M. Williams, Oxford: Blackwell, 2004, 237.
} 
As Nordic governments open up for a renewed global scramble for Arctic resources, protests over specific sites are growing into something more principled. In Norway and Sweden, in particular, new rounds of concessions for resource extraction have drawn widespread alarm alongside anxiety about the possible economic consequences for existing businesses in the North. This latest push for expansion in mineral extraction is being interpreted locally as a renewed wave of colonisation of the North, not just by the South, but by global capital more generally. Although the discourse of colonial "scramble" is criticised for being alarmist and potentially disempowering (Ayers 2013; see also Huggan in this volume), the intrusion of global capital into sensitive areas can be deeply destabilising. What is happening in Sweden (and in Norway and Finland) is not colonisation of one state by another, as the African literature on the subject typically describes it, but rather the internal colonisation by the state of land made use of by indigenous people, for the benefit of international investors. As the state projects parts of its territory as "empty" or "underused," it plays on longstanding colonial discourses that have envisaged nature as resource, and indigenous peoples as immaterial. In these discourses, valuable industries such as tourism, fishing, and herding are rendered worthless in favour of the financialised industries of resource extraction. As with all political actions, proposals, policies, and decisions are supported by a range of performances - attempts both to persuade different social actors to engage in the policy's ambitions and to dampen dissent (see Abram and Weszkalnys 2013; also Abram 2011). Seeking increased economic activity and industrial employment in the North, the Swedish government has been using established techniques to persuade local councils of the inevitability of minerals extraction by emphasising the statistical representation of low economic activity in the North, thus making income the persuasive factor in local decision making. Even as particular cases are played out in the council chambers of local government, competing performances of local place and economics are emerging based on quite different characterisations of life in the North and highlighting the value of ecological sustainability and the continuity of territorial traditions. These performances cast the desire to exploit natural resources for profit as an extension of the colonial mentality, calling up anger and defiance rooted in generations of perceived injustice and ethnic prejudice.

In this chapter, I ask how "the postcolonial" plays out through the clash between extractive industries, ecological traditions, and tourism in the European High North. Whereas much of the critical tourism literature has been concerned for many years with the "authenticity" of indigenous or other local cultures performed for tourists, this chapter addresses a rather different set of questions. While Sámi tourism has been seen by the Nordic states and Sámi organisations alike as a potential economic resource that might also help sustain Sámi ways of living, tourism also presents opportunities for political activism. Insofar as it is a means to help sustain Sámi practices, tourism becomes a political act in Sápmi, but as recent events have shown, events and activities that occur ostensibly in the name of tourism can be opportunities for communication, promotion, and the performance of political solidarity. Thus, in this chapter, tourism, politics, conflict, environmentalism and art must all be considered together, though the strictures of linear text mean that they must be presented one after another, in serial form.

\section{Sweden and Sápmi}


The territory of Fennoscandia has long been contested. Inhabited for over 10,000 years, rockcarvings of reindeer herding have been dated to the fifth millennium BC and were continuously produced over a 5,000-year period (Helskog 2012). The colonial history of the region is much more recent. Colonisation from the South during the Viking period grew sporadically through the Middle Ages; encouragement followed from the Swedish and Norwegian states from the seventeenth century onwards; then recognisable state nationalism in the nineteenth and twentieth centuries ushered in explicit attempts to nationalise the respective populations. Sápmi, the territory that is home to diverse Sámi peoples, was not divided between the Scandinavian nation-states until the nineteenth century, but the closure of borders to reindeer herding in 1852 was a watershed moment in Sámi history, reinforced in 1889 with the closure of borders between Finland and Sweden and through subsequent conventions on reindeer movements and the violent effects of the Second World War (Pedersen 2004). While the details of colonisation in Norway, Sweden, Finland and Russia inevitably differ, there are broad similarities in intent and effect. In Norway and Sweden, attempts to settle nomadic Sámi, and to "nationalise" them into Norwegians and Swedes, deployed many of the methods familiar from global colonial histories. The outlawing of spoken languages and clothing, mandatory schooling, and the enforcement of settled housing were among techniques that were often brutal not just in physical, but also in emotional and psychological terms. Even if most of the laws and policies have since been rescinded, repression and symbolic as well as physical violence are still all too apparent in the continued expression of racism and equally persistent fears among Sámi families about its long-term effects. It is worth repeating here that population figures for Sámi are inherently unreliable since so many people of Sámi descent remain reluctant to identify themselves officially as Sámi, either in everyday life or in relation to authorities. Figures for the number of people on the electoral register for the Norwegian Sámi parliament are revealing, having grown from 5,500 to 14,000 over twenty years - a rise inexplicable without the understanding that increasing numbers of people are publicly recognising their Sámi political identity and registering to vote in parliament. In this context, authoritative statements such as those found in the publications of the Swedish Sámi parliament (published with the Agriculture Ministry: Kvarfordt et al. 2004) - that there are 70,000 Sámi of which 20,000 are in Sweden -are highly misleading. It is likely that the figures are significantly higher. A figure of 2,500 Swedish Sámi involved in reindeer herding is also likely also to be inaccurate since herding spills out into associated activities, including the processing of meat, skins, antlers and other elements, the provision of equipment (including snowscooters), and the exchange of services for travelling herders. Population statistics are notoriously unreliable, but in relation to mixed ethnic groups within a nation who have been subject to assimilation and settlement policies, they must be treated with particular caution.

I will not rehearse the well-documented history of Sámi subjugation here (see, for example, Lundmark 2008), but restrict myself to some of the aspects of what can be called domestic colonialism that are attracting political attention in the current Swedish context. Paramount among these is the Swedish history of race-biology, which would emerge strongly in the last decade of the nineteenth century then flourish in the early twentieth in the form of the Swedish Institution for Race-biology, founded in 1922, which finally closed its doors as late as 1958. Throughout the same period, Sámi children were removed from their homes and forced to attend boarding schools for nomads with the intention of "civilising" them (if not necessarily "Swedifying" them, in contrast to the Norwegianisation programme in the neighbouring country). Such interventions were designed to disrupt the reproduction of cultural knowledge 
by distancing children from their families and communities, and the pain of this enforced separation, along with the humiliation of being subject to the Institute for Race Biology, continued through the generations, as Katarina Pirak Sikku documented in a well-received exhibition in 2014. ${ }^{4}$ That colonial discourses about the Sámi live on in Sweden was also apparent in 2015, when 59 academics came together to object to the use of the language of race-biology in a legal case over hunting and fishing rights in Sámi territory. ${ }^{5}$ Meanwhile, in both Norway and Sweden historical recognition of Sámi has been primarily associated with reindeer herders, effectively deracinating the majority of Sámi who engage in fishing and other forms of subsistence agriculture and trade. Ween and Lien (2012) gently point to the idea of reindeer-herding Sámi as "super-Sámi" in the context of ongoing attempts to re-legitimise the notion of non-reindeer-herding Sámi, acknowledging in the process that there are many different Sámi groups, speaking many different languages, across the expanse of Sápmi.

Whereas in Norway, government plans to dam major rivers over Sámi territories for hydroelectric dams provided the spark for uprisings that would eventually lead to a royal apology and the establishment of the Sámi parliament (in 1989) forced relocations in Swedish Sápmi did not lead to such uprisings, but took place on an even larger scale. The pain of forced removal from ancestral land produced deep communal trauma that is only now gaining broader recognition. Those who were young children or teenagers during the years of the removals are now adults, and some have become unwaveringly politicised and increasingly emboldened in their political practice, as I will go on to discuss in more detail below.

Resistance to the acknowledgement of Sámi rights can also be detected in the refusal of the Swedish government to sign up to ILO convention 169, the Indigenous and Tribal Peoples Convention (1989), despite its adoption under the UN's 2007 Declaration on the Rights of Indigenous Peoples (UNDRIP). The Sámi parliament in Sweden is the most recently established of the three corresponding bodies (Finland's was founded in 1973, Norway's in 1989, and Sweden's in 1993). Each of the parliaments has statutory advisory status, its selfdesignated role being to uphold the rights of Sámi citizens in their respective countries, and to monitor Sámi issues. The Swedish Sámi parliament is not an organ for self-government, however, but rather disburses limited funds for Sámi cultural activities and is the official management body for the reindeer-herding industry in Sweden. Although an architectural competition was held to build a Sámi parliament, internal disputes have meant that construction has been indefinitely postponed. In brief, it could be argued that in contrast to the Norwegian situation, where Sámi politics are well developed and rights established, the Swedish Sámi situation is significantly more fragile, reflected in the continued use of the term "Lapp" as an external ethnic marker - one that has been considered inappropriate for some time now in Norwegian popular consciousness and political debate. In partial acknowledgement of this issue, the national tour operator Visit Sweden advises tourists on its website that the atmosphere "will be super if you refer to them as Sámi and refer to their territory as Sápmi," while referring nevertheless to Sámi as "a people" and using prominent photographs of reindeer. Against the background of institutionalised colonialism and racism, common misunderstandings can take on deeper significance. The common assumption exclusively linking Sámi identity and reindeer herding has been contested in both Norway and Sweden,

\footnotetext{
${ }^{4}$ http://www.bildmuseet.umu.se/en/exhibition/katarina-pirak-sikku/12046 (accessed 1.09.15).

${ }^{5} \mathrm{http} / / /$ www.dn.se/debatt/rasbiologiskt-sprakbruk-i-statens-rattsprocess-mot-sameby/ (accessed 1.09.15).
} 
but it persists in the non-Sámi and southern popular imagination, and is reproduced repeatedly in tourism literature.

\section{Can tourism be Sámi too?}

To describe tourism as "Sámi tourism" raises many of the more difficult questions about Sámi identification arising from a deeply layered history the surface of which is barely scratched above. By what criteria can tourism be described as Sámi? Is it in respect of those who carry out the tourism activities, or those who earn an income from it, or those who own and sell the tourism product, or the signs and emblems that mark the product itself as "Sámi"? The tourism industry generally operates by cultivating exotic stereotypes of people and places to generate desire on the part of potential tourists to travel (Franklin 2004; Viken 2000); and, as Olsen explains, the Sámi have been similarly "constructed" as "touristic emblems" (Olsen 2010). Reni Wright (2014) summarises the difficulties of marking tourism products with ethnic or identity traits, highlighting the essentialism that has long been criticised in tourism "authenticity" debates (summarised in Franklin, 2003). Contested rights to use indigenous emblems, designs, and other aspects of intellectual property have long been discussed in tourism anthropology, along with the imagination of what "indigenous art" is among colonial authorities (see, for example, Graburn 2004), discussions that are relevant to the use and abuse of Sámi designs in marketing and other sales techniques (see Kramvig and Flemen, forthcoming). Striking in Kramvig and Flemen's examples is the shock that many non-Sámi designers express that their use of Sámi symbols might be interpreted as cultural commodification or colonial exploitation. If Swedish designers consider artistic innovation to include the adoption of patterns or designs found in the world around them, Sámi designs are just another instance of creative inspiration, but this fits poorly with the political currency of emblems of Sámi belonging and kinship. The issue here goes beyond a question of freedom of expression and intellectual property, encroaching into the territory of epistemological difference. The understanding of symbols is categorically different in each perspective; quite possibly irreconcilably different.

Despite these difficulties, northern tourism boards have adopted policies to promote Sámi tourism - however defined - even if some Sámi entrepreneurs have complained of being sidelined by the larger operators (Larsen 2009). Swedish tourism policy has explicitly supported the development of Sámi tourism for over a decade, with some discussion about whether directing policy only at reindeer herders is appropriate, given that they are a minority of the Sámi population (see Müller and Pettersson 2006). Rather than set out criteria for identifying Sámi tourism, my focus here is on an event which is, and has always been identified as, a Sámi event, and has increasingly become a tourist attraction for diverse audiences. According to Jokkmokk's municipality, the Sámi Winter Market in Jokkmokk (Swedish Sápmi) has been an annual event since the Swedish King Charles IX established an annual market there in 1605. The granting of an official market licence can be contextualised in efforts to extract taxation from Sámi trade, and played an important part in the Christianisation of the North. The building of a church in Jokkmokk in 1753 meant that visiting Sámi could have their children baptised during the annual market, and hold funerals. Over several centuries, the market expanded to become an important trading point, not only between Sámi from across Sápmi, but also for all kinds of traders in the north, including Russians, Swedes, Norwegians and Finns. Early markets 
may have lasted for two or three weeks, since it was difficult to reckon on the time needed to travel long distances in winter.

The market's twentieth-century history is punctuated by two important developments. In 1943, a crafts college was established in Jokkmokk, rapidly becoming the centre for Sámi arts and craft production ("Duodji") across the region. While there has always been a sense in which grand markets such as this are festive events, the Jokkmokk winter market began its life as a recognisably tourist event with the jubilee market in 1955, by which time many of the formerly nomadic reindeer herders had been more or less settled. Over subsequent years, the number of tourists increased along with the number of traders. In recent years, however, the number of visitors has dropped, from 49,700 over three days in 2007 to 39,000 in 2009 and only 20,000 in 2012, although that year was marked by particularly cold weather, with temperatures down to $-40^{\circ}$ keeping many locals away.

The market as such is just one part of the event, which is a festival by any other name. The two main streets and the town square are closed for market stalls; the college is devoted to exhibitions; and the schools, community centres, churches and a number of private houses are opened for exhibitions, along with various shops and municipal buildings. A press office is housed within the tourist office, and various cafes and restaurants hold events, concerts, talks and other meetings throughout the festival week. Pettersson among others has remarked how visible Sámi presence is at the market (2009; see also Müller and Pettersson 2006), which features reindeer parades and during which many Sámi wear traditional clothes in bright red, blue, yellow and green wool, with silver decoration. The tourist highlight of each day is the parade of a Sámi reindeer sledge through the market onto the festival stage in the town square (renrajd), with the family at times almost overwhelmed by cameras pressing in and people stepping in for photographs.

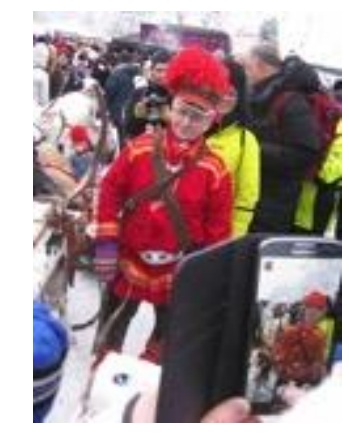

Renraijd at 2014 market. (Photo: Simone Abram)

Prominently on display and sale are intricately crafted duodji items, including knives with carved and inlaid horn and bone handles, silver and leather jewellery, leather and fur clothing and boots, decorative bone cravat-rings, handcrafted reindeer-leather bags, and other items of decoration, clothing, and utility. The craft college holds a fashion show displaying the work of graduating students, and hosts a market within the college premises of craft materials and duodji work. The Duodji Institute also has a special gallery display of the best Sámi artists' work, with special prizes and awards, and there are several venues where professional $d u o d j i$ 
artists can display and sell their work. A feverish sense of splendour marks the occasion, with the very best duodji artists and craftspeople presenting their latest work. (Artists' previews, and shops and stalls selling artists' and craft materials for the abundant production, clearly go on across Sápmi throughout the year.) Similarly, the well-established Ájtte museum, with its shop and café, is an important venue for events, talks, and concerts during the festival, and holds special exhibitions alongside its Sámi history collection. In recent years, a number of Sámi artisanal shops have opened in Jokkmokk, notably the Viltok sisters' art and couture design shop and the Stoorstålka Sámi design shop, thereby reinforcing a visible Sámi presence year-round and playing an important role, not just as a sales-point, but also as a location for meeting and socialising during the festival. In other words, this is not a spectacle for tourists, but a major artistic event in the Sápmi calendar, albeit one open for tourists to attend. While tourists are also free to buy, much of the work on sale is of high quality and attracts correspondingly high prices, and little of the work available in the artists' galleries is the kind that attracts a casual purchase though cheaper versions of some items are available in the main outdoor market area.

\section{Tourism as a platform}

In the last three years, the market has taken an unexpected turn in response to local political events. ${ }^{6}$ As from 2012, protests have regularly been staged at the market against proposed new mining concessions in the area, ${ }^{7}$ with a lively protest march winding through the town, chanting "what shall we do, stop the mines!", followed by dignified political speeches about the colonialism of the Swedish state. Further context is necessary here. The Swedish government (up to 2015) pursued a policy of resource exploitation in the North, and indeed there is a long history of mining in northern Sweden, most famously around the city of Kiruna, parts of which are now being demolished and rebuilt as the city's foundations are being gradually weakened by underground mine workings (Storm 2014). From Stockholm, i.e. the perspective of the state capital (Scott 1998), the government appears to perceive the North as being racked by underemployment and poverty, yet at the same time as being blessed with rich resources. Few people I spoke to in the Northern area could account for any other reason as to why the state would offer mining concessions to foreign companies in return for negligible tax returns, for all intents and purposes giving away the country's national natural resources (with taxes set under $0.5 \%$, in comparison to mining taxes of nearer $30 \%$ in, for example, Australia). A visiting civil servant confirmed that the government view had been a problem-solving approach, seeing increased mining as an efficient way of relieving unemployment and low levels of reported economic activity in the North (Feb. 2015, pers. comm). Such a view ties in with the colonial view of Sápmi as "empty" (see Abram and Lund 2016), a view vigorously contested across the North (see, for example, Rybråten 2013; Ween and Lien 2012; Ween 2009) yet consistently reproduced in both tourism promotional material and state environmental policy (Sandell 1995).

\footnotetext{
${ }^{6}$ Discussion is partly based on field visits to the market in 2014 and 2015, with Britt Kramvig. I thank Britt Kramvig for her insights and guidance during these visits.

${ }^{7}$ Chatham House report increased levels of dispute in the extractive sector globally in the decade 2001-2010 (Stevens et. Al. 2013).
} 

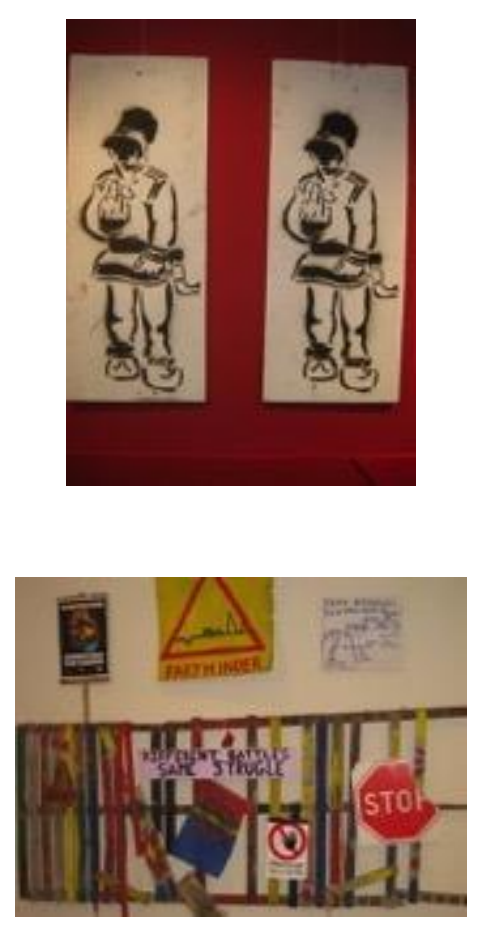

Artwork from the protest movement, exhibited in 2014. (Photos: Simone Abram)

Anger had been sparked in 2012 by comments made by the CEO of the British company, Beowulf, the then holders of the mining concession. The CEO had been filmed saying that his standard response to enquiries about local people's reactions to mining was to show an image of the "natural" tundra landscape and ask them "what local people?"8 The use of such explicitly colonial discourse of tabula rasa, along with its attendant assumption that the area was unpopulated, was intensely provocative, and a website almost immediately appeared entitled "what local people", showing a series of images of local residents accompanied by the phrase: "Here are local people. We are the local people!" The CEO's actions inflamed an already tense situation, rallying support for the cause and turning it from a conflict of interest into a colonial rebellion. Mattias Åhrén, president of the Human Rights committee of the Sámi council, duly presented a case to the UN Racial Discrimination Committee against the Swedish government for discrimination against Sámi caused by its minerals policy. The government had already been criticised by the UN Race Discrimination Committee for not taking Sámi rights into account in developing its mining policies, one of several recent reprimands from the UN about Sámi rights. The crux of the case was that the mining policy was directly detrimental to reindeer herding in the region, and thereby undermined the legally enshrined rights of Sámi herding communities (Eklund 2013).

2013 would also see a series of lively non-violent protest actions to block the road to the exploration-drilling site, Swedish environmentalists joining forces with local protesters who in turn summoned the power of artistic intervention to fortify their sit-in actions. Indeed, the whole movement to date has been characterised by the incorporation of protest art, with Sámi artists occupying increasingly prominent roles in the actions, including a number of recognised

\footnotetext{
${ }^{8}$ See https://www.youtube.com/watch?v=-FPeOPTDhio (accessed 6.12.15).

${ }^{9} \mathrm{http}: / / \mathrm{www}$. whatlocalpeople.se/about/.
} 
figures from a new generation of Sámi artists, prominent among them Anders Sunna, whose work includes stencil-work portraying Sámi men in traditional costumes with AK47s slung over their backs holding up a finger up to authority, and traditional reindeer-sled processions carrying missile launchers (see Fig. 2). In addition, social media have been used to disseminate videos of the protests, showing policy and security agents violently destroying the blockades and dragging passive protesters from the road (including an octogenarian Sámi man), as they were singing and shouting against the mines. The aforementioned exhibition brought together videos, posters, sculptural installations and other items from the protests, and activists were on hand to distribute information, to sell badges and other items to raise money, and to sign people up to the cause.

The next year, in 2014, tensions were running high at the Jokkmokk market after the local authority voted to allow mining explorations to take place around Gállok, an area traditionally used by reindeer herders. ${ }^{10}$ Newspaper coverage focused on Sámi members of the local council, who had voted for the mining concession, suggesting that the split in the council was not simply along "ethnic" lines, but followed more general political-economic axes (Nyberg 2014). Tourists arriving at the market in 2014 were met, accordingly, with a series of political protests and demonstrations. At the conference and community centre next door to Ajtte, an exhibition brought together artwork and installations that had been built the previous summer during protests against the allocation of mining concessions in nearby Gállok. In the town, illfeeling was made manifest through the boycott of the market by various Sámi artists. The Viltok sisters closed their shop at what is normally the height of their season, placing a large sheet of brown paper in the window with an explanation of their absence. Having participated in the market all their lives as guests, artists, salespeople, and having raised awareness of Sámi cultural life and promoted Jokkmokk, the sisters expressed a feeling of betrayal over the authority's granting of a mining licence that would, if put into effect, destroy the main livelihood in the region: reindeer herding. Unable to take two conflicting positions, they chose to boycott the market in 2014 and take their work elsewhere (see Fig. 3). The irony of the municipality choosing the theme of "Reindeer" for the annual market in the year that reindeer herding was threatened as never before only added to the anger felt by many of the protesters.

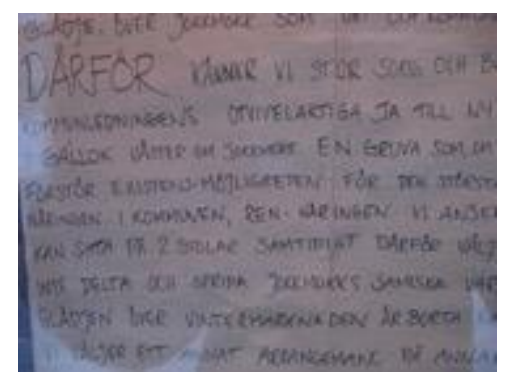

Notice of the boycott in the window of the Viltok sisters' boutique, 2014. (Photo: Simone Abram)

${ }^{10}$ See map of "samebyar" (herding territories) http://www.samer.se/4329. 
Perhaps more controversially, on the third day of the festival artists staged an intervention that was hard for tourists to ignore. Every day, a festival highlight is the parade of reindeer through the town (a "renrajd") and onto the main stage, where speeches are held and the reindeer and their owners presented to the audience. Crowds cluster around the picturesque sleds, led by members of a family who have brought reindeer to the market for many years (Fig. 4.) On this particular occasion, though, the procession was not led by a family in brightly coloured Sámi clothes, but by black-hooded figures clothed as skeletons, with the message that reindeer herding would be no more if the mines went ahead.

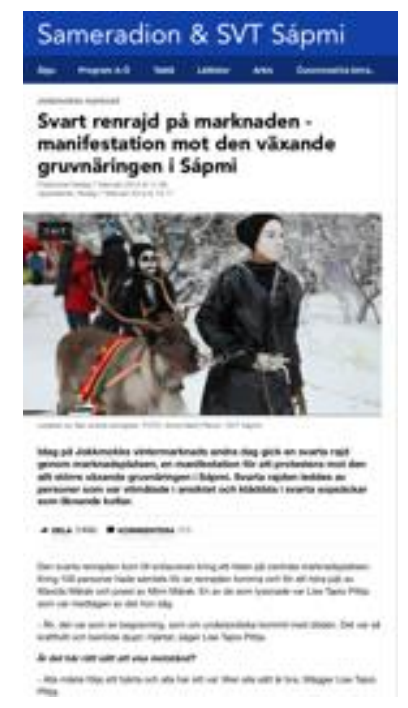

Swedish Radio's report of the Black Reindeer Parade (Svart renrajd). (SVT 7/2/14)

Throughout that year (2014), protests continued with increasingly sophisticated coordination. Summer camps were organised, with information about events and camps being spread on social media, and the protest movement being expanded to tie in with other protests against mineral extractions across Sápmi. (There was also support from environmental groups nationally, and a presence in Stockholm.) By the time of the 2015 market, things had escalated and the protests became even more conspicuous, now addressing general issues around Sámi rights. As observers commented, this was starting to look more like the Alta uprising in Norway in the 1980s, which had been sparked by proposals to dam the Alta River. A sharp drop in international mineral and metal prices, linked to a downturn in the Chinese economy, had led to the concession at Gállok being put on hold, and Beowulf had since sold the concession on. The immediate threat of disruptive works had thus receded, at least for now, but broader questions of racism, anti-Sámi policies, and lack of respect for environmental issues and the voices of local residents had taken centre stage. Other mining conflicts in the region had not gone away, however, and related conflicts in Norway were reinforcing the sense that Sápmi was entering into a new era of re-colonisation from the South.

\section{Ministerial support}


In late 2014, a new Swedish coalition government came to power, with the participation of the Green party. The Minister for Culture and Democracy was a Green party MP famous for her earlier career as a children's TV presenter. For Minister "Alice" (Bah Kuhnke), culture and democracy were intertwined issues for Sweden's Sámi. Kuhnke had already raised the issue when attending the Nobel Peace Prize ceremony in December 2014, resplendent in an upcycled dress commissioned from the Sámi designer Sara Björne. Possibly the first Minister to be invited to attend the Samedagen (Sámi day) celebrations at Jokkmokk, Kuhnke attended the whole of the winter market in 2015, bringing a small group of civil servants and holding meetings with Sámi representatives and youth groups, attending the opening of the Duodji Institute exhibition, and even entering the reindeer-racing tournament on the town's frozen lake. In her speech at the Samedagen event on the main outdoor stage in the market square, Kuhnke referred to a moving meeting she had previously attended at Ájtte on race-biology and skull-measuring, the sense of shame it had provoked, and the urgency of instilling confidence in the new generations of Sámi. In radio interviews, she stressed the importance of securing support for mental health services for young Sámi, and asserted how happy she was to have been appointed Sámi Minister as well as the urgent importance of continuing to campaign against racism and to promote Sámi rights.

There were further events, however, that were not on the Minister's schedule. Outside her hotel, for example, she was met by Mimi and Maxida Märak, Jenni Laiti and others: artists who had been active throughout the anti-mining movement, who had directly confronted the CEO of Beowulf Mining, and who had performed loud rap protests outside the Jokkmokk council. Mimi Märak knelt in front of the Minister, reading aloud from a newly composed Sámi manifesto while her sister Maxida proceeded to shear off Mimi's hair with a knife. The Minister thanked them for their intervention, accepting a copy of their manifesto. Like all of the protest actions, the event was widely announced, discussed, and documented on social media and on websites the number of which has been on the increase since 2013, including kolonierna.se and the Facebook pages for groups including Sámi Manifesta and Gruvfritt Jokkmokk.

By the same means, and also by word of mouth, a larger demonstration at the market was gathering momentum, anticipated in the form of a procession through the town. Local media had heard about the event and reported it as a threat to the market, claiming that many market stallholders were against the demonstration and that the police would divert it. In local news reports, however, all of the stallholders interviewed were positively disposed towards the demonstration for Sámi rights and had negative views on mining. On the day itself, the procession began with a gathering outside Folkets Hus (the town's community centre). A large crowd gathered, some wearing traditional Sámi clothing and others carrying hand-crafted placards agitating for solid ground and clean water for future generations and calling for the Minerals Act to be scrapped. Before the procession set off, several local activists held brief speeches, including Tor Lundberg Tuorda, author of kolonierna.se, who had been active in the anti-mining campaigns from the start. Mimi Märak duly appeared in a long Sámi hooded cloak, holding a megaphone, and proceeded to give a passionate speech to the waiting crowd and the various camera-people and journalists assembled. Calling for respect for Sámi rights, and reading out the newly published manifesto, she fierily declared that she was Sámi through and through, even under her costume, pulling off her long cloak off and standing in leggings and underwear in the freezing temperatures, fists raised. Accompanied by a fiddler playing folk tunes, the procession then moved raucously through town, led by two low-key police attendees, across one market street and along another towards Ájtte. Little overt resistance was 
encountered, though some Sámi participants later reported that they had heard racist comments from bystanders.

\section{Politicising tourism?}

Much has been written, particularly recently, about political tourism (see, for example, Brin 2006; also Frenzel 2014), most of it addressing the travels of activists to participate in political activism around the world. Less has been written on the opportunities that tourism offers to air political grievances or to support political campaigns. Hofmann's recent work on the transformation of tourism souvenirs into political campaign icons opens a set of questions about the extent to which tourism provides both a platform and a means for communicating and pursuing political goals (Hofmann 2015). As Mitchell's history of European tourism to Egypt suggests, the act of going and looking - of deploying what Urry has called the "tourist gaze" (1990) - is itself a political act, made possible and interpreted through a set of political conditions that favour some people and parties over others. As is hopefully clear from the above, the touristic experience of Sámi objects and people at Jokkmokk winter market is shaped by the history of colonial exhibitions. But the market is not simply a neocolonial event; much of it is an arena for Sámi to meet each other, share work, buy and sell artworks and other goods, and socialise. And among the visitors are those who come in solidarity with the ongoing fight for Sámi rights. During the 2015 market, Southern Swedish tourists told me that having been to the north previously on hiking trips, they were horrified to realise the extent to which Sámi people were oppressed, and came back to the market every year as supporters. Others, of course, are oblivious to local conditions and see only the picturesque or the exotic. By staging artistic interventions at the market, the artists and activists at Jokkmokk show how multiple such touristic events can be, uncovering it as a stage both for more conventional forms of tourism (travel, hotels, spectacles, shopping), and a political arena where Sámi people gather from across the region in support of a common cause.

In recent years, the market as a tourist event has been effectively co-opted as a political event through the various actions performed there, including exhibitions such as Anders Sunna's (see above). Sunna's 2015 application to the market organisers to hold an exhibition had been rejected, despite his rapidly rising reputation as a major Sámi artist, but he still went ahead and held the exhibition in an empty shop space provided by the Stoorstalka Sámi design shop. Sunna's designs have been regularly used in the Gállok protests, including work he produced some years ago, having built an artistic profile as a Sámi political artist, and his exhibition has had a constant stream of visitors, including people buying prints and original work. ${ }^{11}$ Sunna is just one of many artists exhibiting work at the winter market, giving his work a context amongst the art and craft that ranges from strictly traditional to boldly creative. The work of the Viltok sisters has also also prominent, and during the 2015 Jokkmokk market their shop was busy from morning until night. After their boycott in 2014, the sisters feared their business would suffer since the market is their main opportunity to show their collections, but they indicated to me that their principled stance had attracted support, not only from their clients, but from other sources including numerous invitations to exhibit their work in galleries. Both exemplify what Viltok has called an awakening among young Sámi: one possible only with the current generation, who are far enough from the forced removals and oppression of the twentieth

${ }^{11}$ See http://anderssunna.com and http://www.saatchiart.com/ASunna. 
century to be freer to act (and less ashamed to be openly Sámi), yet are close enough to understand the dangers of their recent colonial history being repeated. Above all, the events at Gállok described above were the trigger point for younger Sámi to engage in public debate, to address the media, and to use diverse artistic methods to protest.

\section{Conclusion: Performances in conflict}

As I have sought to illustrate in this chapter, the market at Jokkmokk provides a colourful stage for performances of different kinds that bump up against each other, conveying different versions of politics, community, and commerce - and often all of these at once. Recent markets have seen a welling up of political activism, increasingly overt Sámi political resistance, and explicit discussions of colonialism and neocolonialism. Among the activists I spoke to, ${ }^{12}$ the notion of Jokkmokk (or Sápmi more broadly) as a postcolonial space drew some scepticism since the Swedish state and international mining companies are generally seen as acting in a colonial manner, going over the heads of local indigenous populations to pursue a "scramble" for resources in the North. Directly countering colonialist performances by the likes of the Beowulf CEO, activists have drawn on images and narratives that reinforce a different regional story of a region populated but colonised. This narrative demonstrates the deep historical roots (millennia of reindeer herding) of current environmental concerns, but it has also to work against European colonial histories that depict indigenous populations as "natural" peoples. Sámi activists at Jokkmokk and elsewhere have thus drawn on contemporary art practices to highlight the continuity of traditional Sámi activities into the present and future - as evidence of the dignity and sustainability of Sámi life - despite a continuing history of repression and persecution by the state. As I have suggested here, while the protest actions at the site of the mine in Gállok were generally clothed in the pacifist creativity of international environmental protest, ${ }^{13}$ their counterparts at the Jokkmokk market have taken advantage of a ready-made audience, of the presence of notables, and of the gathering of many Sámi families and artists, in the process picking up the more festive, flamboyant style of tourist events.

For visiting tourists, Jokkmokk presents a kind of instant historical experience. The small costumed historical market by the lake that precedes the market proper, where craftspeople from across Sápmi (including Russia) present traditional peasant craft, leads on to the contemporary duodji in the town galleries, then to the political actions which together constitute a kind of fringe festival around the market that questions and challenges the future for Sámi people. During the 2015 market, a young girl from a reindeer herding family was touring the market with a young white reindeer, inviting questions about reindeer herding and Sámi life, with other members of the family quietly present in support. The girl, who was interviewed on local news, explained that she felt it was her duty to explain what reindeerherding life was like, to counter prejudice, and to educate the public about reindeer.

But the tourists at Jokkmokk are not unknown visitors from "abroad," in contrast to their local hosts; rather, Jokkmokk attracts a mixed audience, many of whom see the town as their fulcrum: traders who come to sell; artists who come to show their work to friends and family; college students as well as professional craftspeople who sell at the various indoor markets. Since Jokkmokk is a small town with limited hotel accommodation, many residents open up

\footnotetext{
${ }^{12}$ As noted above, the fieldwork was conducted jointly with Britt Kramvig.

${ }^{13}$ See http://www.faltbiologerna.se/faltbiologen/kallakkriget.
} 
their houses to visitors, renting out rooms, sometimes regularly to the same visitors, year after year. At such an event, the Sámi presence is conspicuously multi-layered; so too the protest action that surrounds it. Among the actions I witnessed at the 2015 market were women campaigning against weapons staging a theatrical march through the streets, dressed in camouflage (see figure X), highlighting the deadly effects of Swedish military shooting ranges in herding areas and questioning why Sámi herders seemed to accept shooting while rejecting mining. One action not to be found, though, was the performative legitimation of mining, which takes place largely in the ministries and parliament in Stockholm, and around the various investment markets for mining. After all, a crash in the market for iron has a more direct effect on mining development than public protest, but a neoliberal belief that markets always recover means that the possibility of profitable mining remains alive even when there is abundant evidence of other nearby mining companies going to the wall. Still, the positive signs are that tourism at Jokkmokk will continue to provide a stage for political action, realised through contemporary artistic practice. The creative use of Sámi symbols, making play on the symbolic language of duodji, offers one example among others of a performative politics for a generation emerging from a long, recent era of Sámi oppression, casting off the shame associated with colonial prejudice and finding a new political voice.

\section{References}

Abram, Simone. Culture and Planning. Aldershot: Ashgate, 2011.

and Katrín Lund. "Green Ice? Tourism Ecologies in the High North." In Tourism Ecologies in the European High North. Edited by Simone Abram and Katrín Lund. London: Palgrave Pivot, 2016.

and Gisa Weszkalnys (eds). Elusive Promises: Planning in the Contemporary world. Oxford: Berghahn, 2013.

Ayers, Alison J. "Beyond Myths, Lies and Stereotypes: The Political Economy of a 'New Scramble for Africa." New Political Economy. 18, no. 2 (2013): 227-257. Doi: 10.1080/13563467.2012.678821.

Baglo, Cathrine. På ville veger?Levende utstillinger av samer i Europa og Amerika. [Gone Astray? Sámi Living Exhibits in Europe and America]. PhD thesis, Tromsø: UiT (Tromsø University), 2011.

Brin, Eldad. "Politically-oriented tourism in Jerusalem." Tourist Studies 6 no. 3 (2006): 215243. Doi: $10.1177 / 1468797607076672$.

Bruner, Edward, and Barbara Kirshenblatt-Gimblett. "Maasai on the Lawn: Tourist Realism in East Africa." Cultural Anthropology 9, no. 2 (1994): 435-470.

Craciun, Adriana. "The Scramble For The Arctic." Interventions, 11 no. 1 (2009): 103-114. Doi: 10.1080/13698010902752855.

Crick, Malcolm. "Sun, Sex, Sights, Savings and Servility: Representations of International Tourism in the Social Sciences." Annual Review of Anthropology 18 (1988): 307-44. 
D'Hauteserre, Anne-Marie. "Postcolonialism, Colonialism and Tourism." In A Companion to Tourism, 235-245. Edited by Alan Lew, C. Michael Hall and Allan M. Williams. Oxford: Blackwell, 2004. Doi: 10.1002/9780470752272.ch19.

Eklund, Nils. "Sverige granskas av FN för rasdiskriminering: mining disturbs reindeer." Sveriges Radio published 18 September 2013. Accessed 8.2.2014.

Franklin, Adrian. Tourism: An introduction. London: Sage, 2003.

"Tourism as an Ordering: Towards a New Ontology of Tourism." Tourist Studies 4, no. 3 (2004): 277-301. Doi: 10.1177/1468797604057328.

Frenzel, Fabian, Feigenbaum, Anna and Patrick McCurdy. "Protest Camps: An Emerging Field of Social Movement Research." The Sociological Review 62, no. 3 (2014): 457-474. Doi: 10.1111/1467-954X.12111.

Fusco, Coco and Guillermo Gómez-Peña. The Year of the White Bear (performance piece), 1992.

Gomez-Peña, Guillermo. The New World Border: Prophecies, Poems \& Loqueras for the End of the world. San Fransisco: City Lights, 1996.

Graburn, Nelson and Jafar Jafari. "Introduction: Tourism Social Science.” Annals of Tourism Research. 18 (1991): 1-11. Doi: 10.1016/0160-7383(91)90035-A.

H. H. "Authentic Inuit Art: Creation and Exclusion in the Canadian North." Journal of Material Culture 9, no. 2 (2004): 141-159. Doi: 10.1177/1359183504044369.

Helskog Knut. "Ancient Depictions Of Reindeer Enclosures And Their Environment." Fennoscandia archaeologica XXIX (2012): 29-54.

Hofmann, A. Tourism-mobilities as ontological politics: Mobile and material semiotics of the bombs on the Plain of Jars, Lao P.D.R. PhD Thesis, Leeds Beckett University, 2015.

Jackson, Taylor. Fraser Institute Annul Survey of Mining Companies. Vancouver: fraserinstitute.org, 2014.

Knobblock, Ina. Sámi Feminists Against Mines. Unpublished conference paper, Lund University, 2014.

. NORA Nordic Journal of Feminist and Gender Research 23 no. 4 (2015).

Kramvig, Britt and Anne Britt. Flemmen. "What Alters When the Sami Traditional Costume Travels? Affective Investments in the Sápmi." In Sensitive Objects: Affects and Material Culture. Edited by J. Frykman and M. P. Frykman. Lund: Nordic Academic Press, forthtcoming.

Kristoffersson, Mathias. "Hatet mot samer sprider sig.” Folkbladet, March 13, 2015.

Kvarfordt, Karin, Nils-Henrik. Sikku and Michael Teilus with National Sámi Information Centre. Samer - ett ursprungsfolk i Sverige [Sámis, an Indigenous People in Sweden]. Västerås: Edita Västra Aros, 2004.

Larsen, Hanne. "Advarer mot samisk turisme.” Altaposten, June 23, 2009 (updated August 29 2012) accessed January 19, 2015. 
Lundmark, Lennart. Stulet land: Svensk makt på samisk mark. Stockholm: Ordfront förlag, 2008 .

Müller, Dieter K. \& Robert Pettersson. "Sámi Heritage at the Winter Festival in Jokkmokk, Sweden." Scandinavian Journal of Hospitality and Tourism, 6, no. 1 (2006): 54-69. Doi: $10.1080 / 15022250600560489$.

Nash, D. 1989 [1977]. "Tourism as a Form of Imperialism." Hosts and Guests. Edited by V.Smith. Philadelphia: University of Pennsylvania Press: 37-52.

Nyberg, Micke. "Jokkmokks kommunalråd ser dystert på politiken." Nordnytt, February 5, 2014 (http://www.svt.se/nyheter/regionalt/norrbotten/jokkmokks-kommunalrad-ser-dystertpa-poltiken).

Olsen, Kjell. "The Touristic Construction of the 'Emblematic' Sámi 1." Acta Borealia: A Nordic Journal of Circumpolar Societies 20, no. 1 (2003): 3-20. Doi: $10.1080 / 08003830310001256$.

Palmer, Catherine. "Tourism \& Colonialism: The Experience of the Bahamas." Annals of Tourism Research 21, no. 4 (1994): 792-812. Doi: 10.1016/0160-7383(94)90084-1.

Pedersen, Steinar. “Gränslös näring i Sverige-Norge.” In Samer - ett ursprungsfolk i Sverige, 34-35. Edited by Karin Kvarfordt, Nils-Henrik Sikku and Michael Teilus. Västerås:Edita Västra Aros, 2004.

Pettersson, Robert. "The Sámi Winter Festival in Jokkmokk, Sweden.” In Nordic Tourism: Issues and Cases, 216-219. Edited by C. Michael Hall, Dieter K. Müller, Jarkko Saarinen. Bristol: Channel View Publications, 2009.

Picard, David. Tourism, Magic and Modernity: Cultivating the Human Garden. Oxford: Berghahn, 2011.

Rybråten Stine. "This is not a wilderness. This is where we live." Enacting nature in UnjárgaNesseby, Northern Norway. PhD thesis, Oslo University, 2013.

Sandell, Klas. "Access to the 'North' - But to What and for Whom? Public Access in the Swedish Countryside and the Case of a Proposed National Park in the Kiruna Mountains." In Polar Tourism: Tourism in the Arctic and Antarctic Regions, 131-145. Edited by Colin Michael Hall and Margaret Johnston. New York: Wiley and Sons, 1995.

Sale, Richard, and Eugene Potapov. The Scramble for the Arctic: Ownership, Exploitation and Conflict in the Far North. London: Frances Lincoln Limited, 2010.

Scott, James C. Seeing Like a State: How Certain Schemes to Improve the 31 Human Condition Have Failed. New Haven, Yale University Press, 1998.

Stevens, Paul, Jaakko Kooroshy, Glada Lahn and Bernice Lee. Conflict and Coexistence in the Extractive Industries. London: The Royal Institute of International Affairs, 2013.

Storm, Anna. Post-Industrial Landscape Scars. NY: Palgrave Macmillan, 2014.

Urry, John. The Tourist Gaze: Leisure and travel in contemporary societies. London: Sage, 1990. 
Viken, Arvid. "Turismens essensialiserende effect: samisk kultur i lys av en tiltakende turisme." In Kulturens materialisering: identitet og uttrykk, 25-52. Edited by S. R. Mathisen. Kristiandsand: Høyskoleforlaget, 2000.

Ween, Gro B. "Blåfjella/Skjækerfjella nasjonalpark: Om forvaltning og utøving av sted." Norsk antropologisk tidsskrift. 1-2 (2009): 95-109.

and Marianne Lien. "Decolonialization in the Arctic? Nature Practices and Land Rights in the Norwegian High North." Journal of Rural and Community Development 7, no. 1 (2012): 93-109.

Wright, Reni Jasinski. Samisk reiseliv \& salg av kulturuttrykk. Report for Sámi Tourism (samisk reiseliv). Tromsø, 2014. (http://www.origonord.no/autoweb/dokument/Samisk\%20Reiseliv\%20og\%20salg\%20av\%20 kulturuttrykk\%20av\%20Reni\%20J\%20Wright.pdf accessed 1.9.2015). 